\title{
New Insights into the Evolution of Intronic Sequences of the $\beta$-fibrinogen Gene and Their Application in Reconstructing Mustelid Phylogeny
}

\author{
Li Yu ${ }^{1,2}$, Jiang Liu ${ }^{1,2}$, Peng-tao Luan ${ }^{1,2}$, Hang Lee ${ }^{3}$, Muyeong Lee ${ }^{3}$, \\ Mi-sook Min ${ }^{3}$, Oliver A Ryder ${ }^{4}$, Leona Chemnick, \\ Heidi Davis ${ }^{4}$ and Ya-ping Zhang ${ }^{1,2 *}$ \\ ${ }^{1}$ Laboratory for Conservation and Utilization of Bio-resource, Yunnan University, Kunming 650091, China \\ ${ }^{2}$ Laboratory of Molecular Biology of Domestic Animals, and Cellular and Molecular Evolution, \\ Kunming Institute of Zoology, Kunming 650223, China \\ ${ }^{3}$ Conservation Genome Resource Bank for Korean Wildlife, BK21 Program for \\ Veterinary Science and College of Veterinary Medicine, \\ Seoul National University, Seoul 151-742, South Korea \\ ${ }^{4}$ Conservation and Research for Endangered Species, Zoological Society of San Diego, \\ P.O. Box 551, San Diego, CA 92112, USA
}

\begin{abstract}
Mustelidae is the largest and most diverse family in the order Carnivora. The phylogenetic relationships among the subfamilies have especially long been a focus of study. Herein we are among the first to employ two new introns (4 and 7) of the nuclear $\beta$-fibrinogen gene to clarify these enigmatic problems. In addition, two previously available nuclear (IRBP exon 1 and TTR intron 1) and one mt (ND2) data sets were also combined and analyzed simultaneously with the newly obtained sequence data in this study. Detailed characterizations of the two intronic regions not only reveal the remarkable occurrences of short interspersed element (SINE) insertion events, providing a new example supporting the attractive hypothesis that attrition of an earlier retroposition may offer a proper environment for successive retropositions by forming a "dimer-like" structure, but also demonstrate their utility in the resolution of mustelid phylogeny. All of our analyses confirm the assemblage of Mustelinae, Lutrinae, and Melinae with confidence; moreover, two clades within Mustelinae were clearly recognized, i.e., genera Mustela and Martes. Notably, genus Martes of Mustelinae was found to branch off first, followed by Melinae and then a clade containing Lutrinae and genus Mustela of Mustelinae, indicating paraphyly of Mustelinae. In addition, Mephitinae diverges before the other mustelids and the monophyletic Procyonidae in all cases, supporting its elevation to a separate family. Additional independent genetic markers are still in need to resolve the trichotomy among Mephitinae and the other two carnivoran clades, Ailuridae and Procyonidae/non-mephitine Mustelidae.
\end{abstract}

Key words: $\beta$-fibrinogen, intron, short interspersed element, SINE, Mustelidae, Mephitinae, phylogenetic analysis

\section{INTRODUCTION}

The family Mustelidae, the most heterogeneous and morphologically diverse family in the mammalian order Carnivora, includes 66 species and is traditionally grouped into five subfamilies: Mustelinae, Lutrinae, Melinae, Taxidiinae, and Mephitinae (Wozencraft, 1989; Yonezawa et al., 2007). Phylogenetic relationships among these subfamilies of living mustelids have been hotly disputed in recent studies and are not yet well established (Bininda-Emonds et al., 1999; Sato et al., 2003, 2004, 2006; Koepfli and Wayne, 2003; Marmi et al., 2004; Flynn et al., 2005; Yonezawa et

\footnotetext{
* Corresponding author. Phone: +86-871-5190761; Fax : +86-871-5195430; E-mail: zhangyp1@263.net.cn
}

al., 2007). The main problem is that Mustelidae represents a typical example of rapid evolutionary radiation and recent speciation events (Koepfli and Wayne, 1998; Marmi et al., 2004), possibly dating back to Oligocene (Wolsan, 1993, 1999; 2005). It even remains ambiguous whether mephitines belongs in Mustelidae, and what their systematic placements are in Order Carnivora, if they are not mustelids. The unresolved trichotomy between Mephitinae and the other two carnivoran clades, Ailuridae and Procyonidae/nonmephitine Mustelidae, has been an evolutionary puzzle over the past few decades (Vrana et al., 1994; Ledje and Arnason, 1996a, b; Dragoo and Honeycutt, 1997; Flynn and Nedbal, 1998; Wolsan,1999; Flynn et al., 2000, 2005; Sato et al., 2004; Delisle and Strobeck, 2005; Fulton and Strobeck, 2006; Yonezawa et al., 2007).

Here, we are the first to employ introns 4 and 7 of the 
fibrinogen gene (FGB) in a phylogenetic study of the Mustelidae. Intron 7 of $\beta$-fibrinogen has been used at different taxonomic levels for birds (Prychitko and Moore, 1997), reptiles (Creer et al., 2003), and carnivorans ( $Y u$ and Zhang, 2005a, 2006), while $\beta$-fibrinogen intron 4 has recently been explored in avian and higher-level carnivoran phylogenies (Barker, 2004; Yu and Zhang, 2006). Interestingly, in the present study, besides providing new insight into the relationships among mustelid subfamilies and the phylogenetic position of Mephitinae relative to the other carnivorans, analyses of these two intronic sequences also reveal the striking occurrences of short interspersed elements (SINEs) insertion events. SINEs are repetitive retroposons less than 500 bp in length that are propagated in eukaryotic genomes by retroposition via an RNA intermediate (Rogers, 1985; Okada, 1991). It has been believed that the enormous dispersion of SINEs may have had a significant impact not only on genomic diversity, but also on regulation of gene expres- sion and function (Deininger, 1989; Maraia, 1995; Shedlock and Okada, 2000).

A comprehensive data set combining the two intronic sequences with previously published nuclear and mitochondrial (mt) data was used here, in both separate and concatenated analyses, with a view to (1) examine the mode of evolution and phylogenetic information in the SINE elements isolated from the two new intronic sequences, (2) evaluate phylogenetic relationships among mustelid subfamilies and investigate the true closest relatives of Mephitinae in Order Carnivora, (3) explore the utility of $\beta$-fibrinogen introns 4 and 7 in the resolution of mustelid phylogeny.

\section{MATERIALS AND METHODS}

\section{DNA samples and PCR amplification}

Ten species representing four subfamilies of Mustelidae (Mustelinae, Lutrinae, Melinae, and Mephitinae) were examined in this study (Table 1). In addition, considering that growing genetic

Table 1. Samples and sequences used in this study

\begin{tabular}{|c|c|c|c|c|c|c|c|c|c|}
\hline \multicolumn{6}{|c|}{ Taxon } & \multicolumn{4}{|c|}{ Gene } \\
\hline Family & Subfamily & Scientific name & Common name & Sample source & $\begin{array}{c}\text { Accession No. } \\
\text { (References) } \\
\text { FGB7 }\end{array}$ & FGB4 & IRBP & TTR & ND2 \\
\hline \multirow[t]{2}{*}{ Canidae } & & Canis lupus & Wolf & $\begin{array}{l}\text { Yunnan Province, } \\
\text { China }\end{array}$ & $\begin{array}{l}\text { AY726652 (Yu \& } \\
\text { Zhang, 2005b) }\end{array}$ & $\begin{array}{l}\text { AY882026 (Yu \& } \\
\text { Zhang, 2006) }\end{array}$ & $\begin{array}{l}\text { AY525044 (Yu \& } \\
\text { Zhang, 2004b) }\end{array}$ & $\begin{array}{l}\text { AF039732 (Flynn \& } \\
\text { Nedbal, 1998) }\end{array}$ & $\begin{array}{l}\text { AY170044 (Yoder } \\
\text { et al., 2003) }\end{array}$ \\
\hline & & Canis familiaris & Domestic dog & - & Genome Database & Genome Database & Genome Database & Genome Database & Genome Database \\
\hline \multirow[t]{3}{*}{ Procyonidae } & & Procyon lotor & Raccoon & $\begin{array}{l}\text { San Diego Zoo, } \\
\text { USA }\end{array}$ & $\begin{array}{l}\text { AY726653 (Yu \& } \\
\text { Zhang, 2005b) }\end{array}$ & $\begin{array}{l}\text { AY882028 (Yu \& } \\
\text { Zhang, 2006) }\end{array}$ & $\begin{array}{l}\text { AY525029 (Yu \& } \\
\text { Zhang, 2004b) }\end{array}$ & $\begin{array}{l}\text { AF039736 (Flynn \& } \\
\text { Nedbal, 1998) }\end{array}$ & $\begin{array}{l}\text { AY170046 (Yoder } \\
\text { et al., 2003) }\end{array}$ \\
\hline & & Potos flavus & Kinkajou & $\begin{array}{l}\text { San Diego Zoo, } \\
\text { USA }\end{array}$ & $\begin{array}{l}\text { AY882046 (Yu \& } \\
\text { Zhang, 2006) }\end{array}$ & $\begin{array}{l}\text { AY882029 (Yu \& } \\
\text { Zhang, 2006) }\end{array}$ & $\begin{array}{l}\text { AY525030 (Yu \& } \\
\text { Zhang, 2004b) }\end{array}$ & $\begin{array}{l}\text { AF039737 (Flynn \& } \\
\text { Nedbal, 1998) }\end{array}$ & $\begin{array}{l}\text { AY882059 (Yu \& } \\
\text { Zhang, 2006) }\end{array}$ \\
\hline & & Nasua narica & $\begin{array}{l}\text { White-nosed } \\
\text { coati }\end{array}$ & $\begin{array}{l}\text { San Diego Zoo, } \\
\text { USA }\end{array}$ & $\begin{array}{l}\text { AY882047 (Yu \& } \\
\text { Zhang, 2006) }\end{array}$ & $\begin{array}{l}\text { AY882030 (Yu \& } \\
\text { Zhang, 2006) }\end{array}$ & $\begin{array}{l}\text { AY525031 (Yu \& } \\
\text { Zhang, 2004b) }\end{array}$ & $\begin{array}{l}\text { AY525054 (Yu \& } \\
\text { Zhang, 2004b) }\end{array}$ & $\begin{array}{l}\text { AY882060 (Yu \& } \\
\text { Zhang, 2006) }\end{array}$ \\
\hline \multirow[t]{10}{*}{ Mustelidae } & Mustelinae & Martes flavigula & $\begin{array}{l}\text { Yellow-throated } \\
\text { Marten }\end{array}$ & $\begin{array}{l}\text { Kunming Zoo, } \\
\text { China }\end{array}$ & $\begin{array}{l}\text { AY726654 (Yu \& } \\
\text { Zhang, 2005b) }\end{array}$ & $\begin{array}{l}\text { AY882031 (Yu \& } \\
\text { Zhang, 2006) }\end{array}$ & $\begin{array}{l}\text { AY525048 (Yu \& } \\
\text { Zhang, 2004b) }\end{array}$ & $\begin{array}{l}\text { AY525050 (Yu \& } \\
\text { Zhang, 2004b) }\end{array}$ & $\begin{array}{l}\text { AY882061 (Yu \& } \\
\text { Zhang, 2006) }\end{array}$ \\
\hline & & Martes zibellina & Sable & $\begin{array}{l}\text { Haerbin Zoo, } \\
\text { China }\end{array}$ & $\begin{array}{l}\text { AY882048 (Yu \& } \\
\text { Zhang, 2006) }\end{array}$ & $\begin{array}{l}\text { AY882032 (Yu \& } \\
\text { Zhang, 2006) }\end{array}$ & $\begin{array}{l}\text { AY525047 (Yu \& } \\
\text { Zhang, 2004b) }\end{array}$ & $\begin{array}{l}\text { AY525051 (Yu \& } \\
\text { Zhang, 2004b) }\end{array}$ & $\begin{array}{l}\text { AY882062 (Yu \& } \\
\text { Zhang, 2006) }\end{array}$ \\
\hline & & Martes foina & Stone Marten & $\begin{array}{l}\text { Kunming Zoo, } \\
\text { China }\end{array}$ & $\begin{array}{l}\text { EU021485 } \\
\text { (this study) }\end{array}$ & $\begin{array}{l}\text { EU021492 } \\
\text { (this study) }\end{array}$ & $\begin{array}{l}\text { AB082965 (Sato et } \\
\text { al., 2003) }\end{array}$ & $\begin{array}{l}\text { EU021499 } \\
\text { (this study) }\end{array}$ & $\begin{array}{l}\text { EU021504 } \\
\text { (this study) }\end{array}$ \\
\hline & & Mustela kathiah & $\begin{array}{l}\text { Yellow-bellied } \\
\text { weasel }\end{array}$ & $\begin{array}{l}\text { Yunnan Province, } \\
\text { China }\end{array}$ & $\begin{array}{l}\text { AY882049 (Yu \& } \\
\text { Zhang, 2006) }\end{array}$ & $\begin{array}{l}\text { AY882033 (Yu \& } \\
\text { Zhang, 2006) }\end{array}$ & $\begin{array}{l}\text { AY525046 (Yu \& } \\
\text { Zhang, 2004b) }\end{array}$ & $\begin{array}{l}\text { EU021500 } \\
\text { (this study) }\end{array}$ & $\begin{array}{l}\text { AY882063 (Yu \& } \\
\text { Zhang, 2006) }\end{array}$ \\
\hline & & Mustela nivalis & Least weasel & $\begin{array}{l}\text { CGRB*, } \\
\text { South Korea }\end{array}$ & $\begin{array}{l}\text { EU021487 } \\
\text { (this study) }\end{array}$ & $\begin{array}{l}\text { EU021494 } \\
\text { (this study) }\end{array}$ & $\begin{array}{l}\text { AB082973 (Sato et } \\
\text { al., 2003) }\end{array}$ & $\begin{array}{l}\text { EU021501 } \\
\text { (this study) }\end{array}$ & $\begin{array}{l}\text { AY750629 (Flynn et } \\
\text { al. 2005) }\end{array}$ \\
\hline & & Mustela sibirica & Siberian weasel & $\begin{array}{l}\text { CGRB }^{*} \text {, } \\
\text { South Korea }\end{array}$ & $\begin{array}{l}\text { EU021486 } \\
\text { (this study) }\end{array}$ & $\begin{array}{l}\text { EU021493 } \\
\text { (this study) }\end{array}$ & $\begin{array}{l}\text { AB082976 (Sato et } \\
\text { al., 2003) }\end{array}$ & $\begin{array}{l}\text { AY750594 (Flynn } \\
\text { et al., 2005) }\end{array}$ & $\begin{array}{l}\text { AY750641 (Flynn et } \\
\text { al. 2005) }\end{array}$ \\
\hline & Lutrinae & Lutra lutra & Eurasian otter & $\begin{array}{l}\text { CGRB*, } \\
\text { South Korea }\end{array}$ & $\begin{array}{l}\text { EU021489 } \\
\text { (this study) }\end{array}$ & $\begin{array}{l}\text { EU021496 } \\
\text { (this study) }\end{array}$ & $\begin{array}{l}\text { dq205884\# (Fulton } \\
\text { \& Strobeck, 2006 ) }\end{array}$ & $\begin{array}{l}\text { EU021503 } \\
\text { (this study) }\end{array}$ & $\begin{array}{l}\text { AY598557* (Delisle } \\
\text { \& Strobeck, 2005) }\end{array}$ \\
\hline & Melinae & Meles meles & Eurasian badger & $\begin{array}{l}\text { CGRB*, }^{\star} \\
\text { South Korea }\end{array}$ & $\begin{array}{l}\text { EU021488 } \\
\text { (this study) }\end{array}$ & $\begin{array}{l}\text { EU021495 } \\
\text { (this study) }\end{array}$ & $\begin{array}{l}\text { AB082980 } \\
\text { (Sato et al., 2003) }\end{array}$ & $\begin{array}{l}\text { EU021502 } \\
\text { (this study) }\end{array}$ & $\begin{array}{l}\text { EU021505 } \\
\text { (this study) }\end{array}$ \\
\hline & & Arctonyx collaris & Hog badger & $\begin{array}{l}\text { Yunnan Province, } \\
\text { China }\end{array}$ & $\begin{array}{l}\text { AY882050 (Yu \& } \\
\text { Zhang, 2006) }\end{array}$ & $\begin{array}{l}\text { AY882034 (Yu \& } \\
\text { Zhang, 2006) }\end{array}$ & $\begin{array}{l}\text { AY525049 (Yu \& } \\
\text { Zhang, 2004b) }\end{array}$ & $\begin{array}{l}\text { AY525053 (Yu \& } \\
\text { Zhang, 2004b) }\end{array}$ & $\begin{array}{l}\text { AY882064 (Yu \& } \\
\text { Zhang, 2006) }\end{array}$ \\
\hline & Mephitinae & Mephitis mephitis & Striped skunk & $\begin{array}{l}\text { San Diego Zoo, } \\
\text { USA }^{\star \star}\end{array}$ & $\begin{array}{l}\text { EU021490 } \\
\text { (this study) }\end{array}$ & $\begin{array}{l}\text { EU021497 } \\
\text { (this study) }\end{array}$ & $\begin{array}{l}\text { AB109331 (Sato et } \\
\text { al., 2004) }\end{array}$ & $\begin{array}{l}\text { AF306948 (Flynn et } \\
\text { al., 2000) }\end{array}$ & $\begin{array}{l}\text { AY598535 (Delisle } \\
\text { \& Strobeck, 2005) }\end{array}$ \\
\hline \multirow[t]{4}{*}{ Ursidae } & & Ursus arctos & Brown bear & $\begin{array}{l}\text { Heilongjiang } \\
\text { Province, China }\end{array}$ & $\begin{array}{l}\text { AY726655 (Yu \& } \\
\text { Zhang, 2006) }\end{array}$ & $\begin{array}{l}\text { AY882035 (Yu \& } \\
\text { Zhang, 2006) }\end{array}$ & $\begin{array}{l}\text { AY303842 (Yu et } \\
\text { al., 2004a) }\end{array}$ & $\begin{array}{l}\text { AF039741 (Flynn \& } \\
\text { Nedbal, 1998) }\end{array}$ & $\begin{array}{l}\text { AF303110(Delisle \& } \\
\text { Strobeck, 2002) }\end{array}$ \\
\hline & & Ursus thibetanus & $\begin{array}{l}\text { Asiatic black } \\
\text { bear }\end{array}$ & $\begin{array}{l}\text { Yunnan Province, } \\
\text { China }\end{array}$ & $\begin{array}{l}\text { AY882051(Yu \& } \\
\text { Zhang, 2006) }\end{array}$ & $\begin{array}{l}\text { AY882036 (Yu \& } \\
\text { Zhang, 2006) }\end{array}$ & $\begin{array}{l}\text { AY303841 (Yu et } \\
\text { al., 2004a) }\end{array}$ & $\begin{array}{l}\text { AY303847 (Yu et } \\
\text { al., 2004a) }\end{array}$ & $\begin{array}{l}\text { AY882065 (Yu \& } \\
\text { Zhang, 2006) }\end{array}$ \\
\hline & & $\begin{array}{l}\text { Tremarctos } \\
\text { ornatus }\end{array}$ & Spectacled bear & $\begin{array}{l}\text { San Diego Zoo, } \\
\text { USA }\end{array}$ & $\begin{array}{l}\text { AY882052 (Yu \& } \\
\text { Zhang, 2006) }\end{array}$ & $\begin{array}{l}\text { AY882037 (Yu \& } \\
\text { Zhang, 2006) }\end{array}$ & $\begin{array}{l}\text { AY303840 (Yu et } \\
\text { al., 2004a) }\end{array}$ & $\begin{array}{l}\text { AF039740 (Flynn \& } \\
\text { Nedbal, 1998) }\end{array}$ & $\begin{array}{l}\text { AY170045 (Yoder } \\
\text { et al., 2003) }\end{array}$ \\
\hline & & $\begin{array}{l}\text { Ailuropoda } \\
\text { melanoleuca }\end{array}$ & Giant panda & $\begin{array}{l}\text { Sichuan Province, } \\
\text { China }\end{array}$ & $\begin{array}{l}\text { AY882053 (Yu \& } \\
\text { Zhang, 2006) }\end{array}$ & $\begin{array}{l}\text { AY882038 (Yu \& } \\
\text { Zhang, 2006) }\end{array}$ & $\begin{array}{l}\text { AY303836 (Yu et } \\
\text { al., 2004a) }\end{array}$ & $\begin{array}{l}\text { AF039738 (Flynn \& } \\
\text { Nedbal, 1998) }\end{array}$ & $\begin{array}{l}\text { AY882066 (Yu \& } \\
\text { Zhang, 2006) }\end{array}$ \\
\hline Ailuridae & & Ailurus fulgens & Red panda & $\begin{array}{l}\text { Yunnan Province, } \\
\text { China }\end{array}$ & $\begin{array}{l}\text { AY882054 (Yu \& } \\
\text { Zhang, 2006) }\end{array}$ & $\begin{array}{l}\text { AY882039 (Yu \& } \\
\text { Zhang, 2006) }\end{array}$ & $\begin{array}{l}\text { AY525045 (Yu et } \\
\text { al., 2004b) }\end{array}$ & $\begin{array}{l}\text { AF039739 (Flynn \& } \\
\text { Nedbal, 1998) }\end{array}$ & $\begin{array}{l}\text { AY882067 (Yu \& } \\
\text { Zhang, 2006) }\end{array}$ \\
\hline Otariidae & & $\begin{array}{l}\text { Zalophus } \\
\text { californianus }\end{array}$ & Sea lion & $\begin{array}{l}\text { San Diego Zoo, } \\
\text { USA }\end{array}$ & $\begin{array}{l}\text { AY882055 (Yu \& } \\
\text { Zhang, 2006) }\end{array}$ & $\begin{array}{l}\text { AY882040 (Yu \& } \\
\text { Zhang, 2006) }\end{array}$ & $\begin{array}{l}\text { AY525043 (Yu et } \\
\text { al., 2004b) }\end{array}$ & $\begin{array}{l}\text { AF039745 (Flynn \& } \\
\text { Nedbal, 1998) }\end{array}$ & $\begin{array}{l}\text { AY750639 (Flynn et } \\
\text { al., 2005) }\end{array}$ \\
\hline Phocidae & & Phoca vitulina & Harbor seal & China & $\begin{array}{l}\text { AY882057 (Yu \& } \\
\text { Zhang, 2006) }\end{array}$ & $\begin{array}{l}\text { AY882042 (Yu \& } \\
\text { Zhang, 2006) }\end{array}$ & $\begin{array}{l}\text { AB188518 (Sato et } \\
\text { al. ,2006) }\end{array}$ & $\begin{array}{l}\text { AY750599 (Flynn } \\
\text { et al., 2005) }\end{array}$ & $\begin{array}{l}\text { AY750640 (Flynn et } \\
\text { al., 1998) }\end{array}$ \\
\hline Odobenidae & & $\begin{array}{l}\text { Odobenus } \\
\text { rosmarus }\end{array}$ & Walrus & $\begin{array}{l}\text { San Diego Zoo, } \\
\text { USA }^{*}\end{array}$ & $\begin{array}{l}\text { EU021491 } \\
\text { (this study) }\end{array}$ & $\begin{array}{l}\text { EU021498 } \\
\text { (this study) }\end{array}$ & $\begin{array}{l}\text { DQ205892 (Fulton } \\
\text { \& Strobeck, 2006) }\end{array}$ & $\begin{array}{l}\text { AF039743 (Flynn \& } \\
\text { Nedbal, 1998) }\end{array}$ & $\begin{array}{l}\text { AY750637 (Flynn et } \\
\text { al., 2005) }\end{array}$ \\
\hline
\end{tabular}

* Conservation Genome Resource Bank for Korean Wildlife, Seoul National University. Data were exchanged after sequencing was conducted in each laboratory.

** Data were exchanged after sequencing was conducted in each laboratory.

\# Sequence from Lontra canadensis, instead of that from Lutra lutra, was obtained for the concatenated analysis. 
evidence supports the exclusion of subfamily Mephitinae from Mustelidae and places it within suborder Caniformia of Carnivora as a separate unresolved clade, we also included 13 non-mustelid caniform carnivorans in our analyses to determine the phylogenetic position of Mephitinae (Table 1). Here, all seven currently recognized extant families of Caniformia, including Canidae, Ursidae, Procyonidae, Mustelidae, Phocidae, Odobenidae, and Otariidae (Eisenberg, 1989; Wozencraft, 1989; Wyss and Flynn, 1993), were represented. We also retrieved published sequences from GenBank for two nuclear genes, part of exon 1 from the gene for interphotoreceptor retinoid binding protein (IRBP) and intron 1 from the transthyretin (TTR) gene, and one mitochondrial protein-coding gene, NADH dehydrogenase subunit 2 (ND2), for these carnivore species (Flynn and Nedbal, 1998; Flynn et al., 2005; Sato et al., 2003; Yu et al., 2004a, b; Yu and Zhang, 2005b, 2006). In addition, we newly sequenced some sequences of these genes from the mustelid species included in this study (Table 1).

For each sample, total genomic DNA was isolated from blood or frozen tissues using standard proteinase $\mathrm{K}$, phenol/chloroform extraction (Sambrook et al., 1989). All target gene segments were amplified by PCR using previously reported primers: FGB-FelF/ FGB-FelR and FGB7-CarF/FGB7-CarR for $\beta$-fibrinogen intron 7 , FGB4-CarF and FGB4-CarR for $\beta$-fibrinogen intron 4, ND2-FelF/ ND2-FelR and ND2-CarF/ND2-CarR for ND2 (Yu and Zhang, 2006), and T635/T1628 for TTR (Flynn and Nedbal, 1998). The optimal conditions adopted for PCR reactions were $95^{\circ} \mathrm{C}$ for $5 \mathrm{~min}$; 35 cycles of $94^{\circ} \mathrm{C}$ for $1 \mathrm{~min}, 50^{\circ} \mathrm{C}$ (for $\beta$-fibrinogen introns 4 and 7 ) or $56^{\circ} \mathrm{C}$ (for ND2 and TTR) for $1 \mathrm{~min}$, and $72^{\circ} \mathrm{C} 1 \mathrm{~min}$; and a final extension at $72^{\circ} \mathrm{C}$ for $10 \mathrm{~min}$.

\section{Sequencing and data analysis}

Amplified PCR products were purified and sequenced in both directions with an $\mathrm{ABI}$ PRISM 3730 DNA sequencer. Acquired sequences were put into GenBank for BLAST searching (Altschul et al., 1997) and data validity was ensured.

Separate alignments of four nuclear gene segments ( $\beta$-fibrinogen introns 4 and 7, IRBP, TTR) and one mt gene sequence (ND2) from 23 caniform carnivores were generated by CLUSTAL X (Thompson et al., 1997) and refined by visual inspection. The $\beta$-fibrinogen intron 4 and 7 alignments exhibited obvious sequence length variation due to multiple insertions/deletions. The two intron DNA sequences were thus screened for interspersed repeats known to exist in mammalian genomes by using the program CENSOR (Kohany et al., 2006; http://www.girinst.org/censor/index.php). Matching elements were detected and assigned to specific repeat classes. Target-site duplications flanking putative SINEs due to the integration at staggered chromosomal breaks (Weiner et al., 1986) were identified by the software REPFIND (Betley et al., 2002) and by eye. Notably, besides orthologous mammalian-wide interspersed repeats (MIRs) and species-specific CAN SINEs in two canid taxa (Canis lupus and Canis rufus) detected within $\beta$-fibrinogen intron 7 (reported recently by us elsewhere; Yu and Zhang, 2005a, b, 2006), two new CAN SINEs were also observed here in Lutra lutra (otter) $\beta$-fibrinogen intron 4 and Mephitis mephitis (striped skunk) intron 7 (hereafter referred as Ott4-ins and Sku7-ins).

Phylogenetic analyses were conducted by using the maximum parsimony (MP; PAUP*4.0b10 software; Swofford, 2002), maximum likelihood (ML; PAUP*4.0b10 software; Swofford, 2002), and partitioned Bayesian inference (pBI; MrBayes3.0B4 software; Ronquist and Huelsenbeck, 2003) methods for the separate and combined datasets, with all species-specific SINEs removed. In the end, 514 and 618 nucleotide positions in the $\beta$-fibrinogen intron 4 and 7 alignment were used in the phylogenetic analyses, respectively (see Supplemental Material). We designated Canidae as the outgroup on the basis of the consensus that Canidae was the earliest diverging lineage within Caniformia (Wyss and Flynn, 1993; Vrana et al., 1994; Flynn and Nedbal, 1998; Yu et al., 2004b, 2006; Delisle and
Strobeck, 2005; Flynn et al., 2005; Fulton and Strobeck, 2006). In MP analyses, a branch-and-bound search strategy with furthest sequence addition and MULPARS was employed. For the modelbased ML analyses, we conducted hierarchical likelihood-ratio tests (hLRT) to compare the goodness of fit of 56 nucleotide substitution models by using ModelTest version 3.06 (Posada and Crandall, 1998). Once an appropriate model was established, a ML tree was constructed based on this model of sequence evolution. The reliability of phylogenetic relationships was evaluated by bootstrap analyses for MP and ML trees (BS; 1000 replicates for MP and 100 replicates for $\mathrm{ML}$ ). The $\mathrm{pBI}$ analysis allowed a separate general time reversible $(\mathrm{GTR})+\mathrm{I}+\Gamma$ model and set of parameters for each gene partition. Four Metropolis-coupled Markov-chain Monte-Carlo (MCMC) analyses were run for 2 million generations, with trees sampled every 100 generations. Robustness of branches in the $\mathrm{pBI}$ analysis was assessed by posterior probability (PP).

In addition, to examine their potential phylogenetic signal, we also subjected the nucleotide sequence data from the orthologous MIRs embedded in $\beta$-fibrinogen intron 7 to phylogenetic analysis by using the three tree-building methods as described above.

\section{RESULTS}

\section{Novel findings on SINE elements in $\beta$-fibrinogen intronic segments}

Our previous study of $\beta$-fibrinogen intron 7 in 12 mammalian orders detected an orthologous MIR and several species-specific CAN SINE insertions in Carnivora (Yu and Zhang, 2005b). MIRs represent one of the oldest tRNAderived SINE elements examined to date, as inferred from its integration into the host genomes before the radiation of mammalian orders (Jurka et al., 1995; Smit and Riggs, 1995), whereas species-specific CAN SINE elements were found to have independently inserted into different nucleotide positions in two feline (Profelis temminckii and Otocolobus manul) and one canine taxa (Canis lupus) (Yu and Zhang, 2005a, b). CAN SINE, as a pan-carnivore SINE family (Vassetzky and Kramerov, 2002), was first found in the American mink, then in the dog and harbor seal (Lavrentieva et al., 1989; Minnick et al., 1992; Coltman and Wright, 1994). Particularly interesting in our previous study is the finding that all identified species-specific SINEs show a strong tendency to insert within or in very close proximity to preexisting MIRs for efficient integration, supporting the attractive hypothesis that attrition of an earlier retroposition may provide a proper environment for successive retropositions (Wang et al., 2004; Yu and Zhang, 2005b).

Here, we extended SINE analyses of the same intron in Carnivora by including Odobenidae and additional taxa of Mustelidae. Interestingly, besides the presence of orthologous MIRs, a 420-bp large insertion located extremely close the 5 ' B box of MIR (at a distance of $37 \mathrm{bp}$ ) was observed uniquely in Mephitis mephitis, a representative of Mephitinae (alignment positions 528-947). On closer examination, sequence analyses revealed that this large insertion consists of two CAN SINEs (named Sku7-ins-1 and Sku7-ins-2) separated by a 9-bp sequence (ATATATTCT), each comprising $195 \mathrm{bp}$ of the intact sub-subfamily SINEC1D_CF in subfamily SINEC1 of the CAN SINEs (Repbase Update Release 9.11, December 2004) and having been inserted in complementary orientation. As can be seen from Fig. 1A, there were perfect 15-bp target-site duplications, CTGACTGC(T)AT(C)ATTCT, flanking the large insertion and amazingly, the 9-bp separation sequence between the 


\section{A Mephitis mephitis (striped skunk) intron 7}

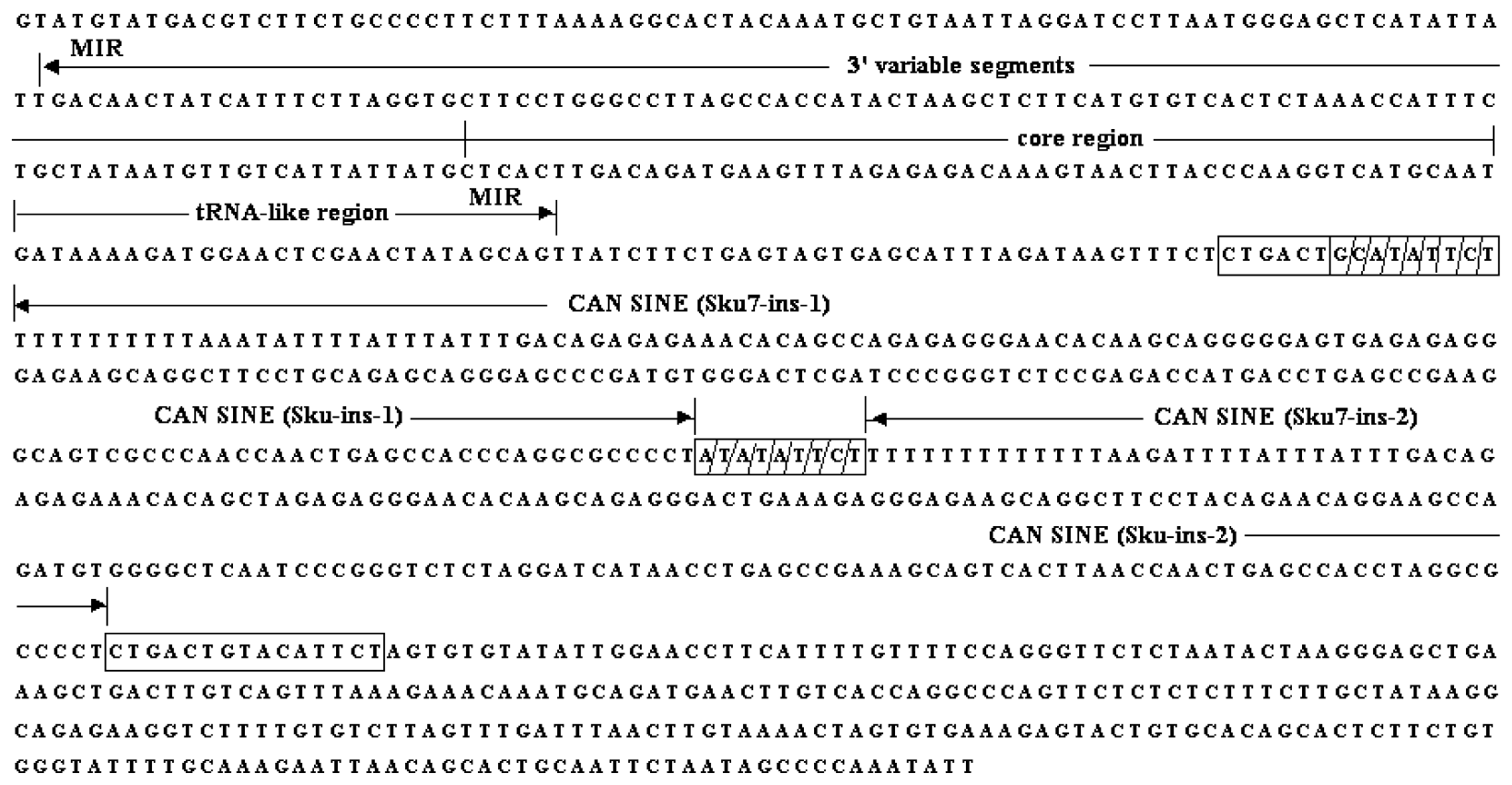

\section{B Lutra lutra (otter) B-fibrinogen intron 4}

ATATT TCAGAGGGTTCTAGAACAAATAGTCTCTAAAAATAAGAGAACTTCAAAAAGCTTAGTGGCTCTTCCCCAACCA CCCTAAT GACAAAAGAGCACAT CAT GAAGATAT CCCTAGCCT GCTGTGT T T GACTTAGCCTAAT TATTTGCCAGTTTG - CAN SINE (Otter4-ins)

T T T T T T TAAGATTATT TAT TATT T GACAGAAAT CACAAGTAGGCAGAGAGGCAGACAGAGAGAGAGAGGAGGAAGCA GGCT CCCT GCCAACAGAGAGCCCGAT T TGGACT CCAT CCCAGGACCCT GGGATCATGACCT GAGCCAAAGGCAGAGAC CAN SINE (Otter4-ins)

TCAACCCCCT GAGCCACCCAGGT GCCCCTATTTGCCAGTTTTT GAT GAATAGAATATAATGTAATGATGATGATAGCT CC ACCTGGCTAAT GCACATTTTTGCTTGGCTAGGTGGCAGAAGCATGGCGGGGAGGAGGGGTATGGAGTTTCTCCATCCCTT GT GTTCT GGCAGGTTATGTATATCCTAGGATATAAAAGGTGAAGAAGGGCTTGTTTCATCCCTTCGGGAAATGGACTCA AAACTGAGTCTGATT TT CAGTAAAAAGAT GATTCAGTTTCTATAATT TATTCTCAAATGTCTAGGATAAAACATTCCTCA GTAACT G GTTATAAATTGATGACTAAAGACCAAGGAGTTATGTTGTAGTTCCCTGAATATATGTTATGTATGTTTG CAGA

Fig. 1. Location and characterization of the new CAN SINEs found in (A) Mephitis mephitis (striped skunk) $\beta$-fibrinogen intron 7 and (B) Lutra lutra (otter) $\beta$-fibrinogen intron 4 . Boxed-case letters in the sequence indicate the direct repeats flanking the SINEs.

two CAN SINE units, which was found to be a partial sequence of the 15-bp duplications, was the target-site duplication for Sku7-ins-1. Therefore, a scenario for the formation of this unusually large insertion in this intronic region can be proposed based on characterization of the two target-site duplications (Fig. 2). Sku7-ins-2 was first inserted near the MIR 5' B box region, producing the 15-bp duplication, and then the Sku7-ins-1 insertion occurred at the $A+T$ rich tail of Sku7-ins-2, producing the 9-bp duplication. The two successive insertions thus gave rise to the seemingly "dimeric" CAN SINE structure discovered here. Indeed, comparisons of the two CAN SINEs with the SINEC1D_CF consensus sequence also revealed that Sku7-ins-2 has higher sequence divergence than Sku7-ins-1 (28.8\% and 24.1\% K2P distance for Sku7-ins-2 and Sku7-ins-1, respectively, calculated in MEGA3 [Kumar et al., 2004]), supporting the earlier insertion of Sku7-ins-2. This feature is consistent with the model we proposed.

Remarkably, besides $\beta$-fibrinogen intron 7 , we also found a new CAN SINE in another intronic sequence of the same gene, in $\beta$-fibrinogen intron 4 (alignment positions 165-366), from Lutra lutra (otter), a representative of Lutrinae. Like Sku7-ins-1 and Sku7-ins-2, this 195-bp full-length CAN SINE was identified to belong to sub-subfamily SINEC1D_CF in subfamily SINEC1 of CAN SINEs (Repbase Update Release 9.11, December 2004). There were 13-bp target-site duplications (TATTTGCCAGTTT) flanking it (Fig. 1B), and this identified CAN SINE sequence differed from the consensus by $17.4 \%$ divergence.

\section{Phylogenetic analyses of two new nuclear data sets}

Fig. 3 shows trees based on separate MP analyses of 


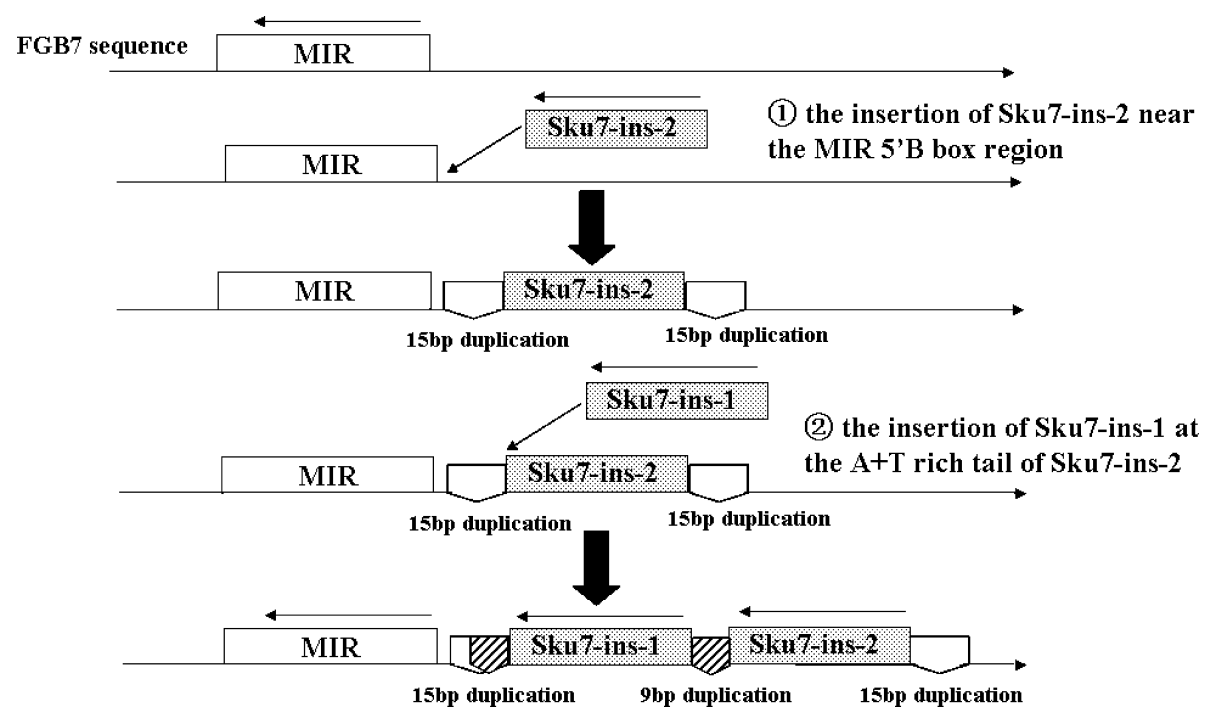

Fig. 2. A proposed model for the formation of the unusually large insertion in Mephitis mephitis intron 7.

$\beta$-fibrinogen introns 7 and 4 (FGB7 and 4). Groups that appeared in $50 \%$ or more of the trees were retained. Of the 618 aligned nucleotides for FGB7, 275 (44.50\%) were variable and $178(28.80 \%)$ were phylogenetically informative. The branch-and-bound search found three most parsimonious trees with a tree length of 380 . The $M L$ (model $=H K Y+G)$ and $\mathrm{pBI}$ analyses recovered a tree topology nearly identical to the MP tree, with similar nodal support. Within Mustelidae, genus Martes of Mustelinae branches off first, followed by Melinae and the clade containing Lutrinae and genus Mustela of Mustelinae. This result indicates the paraphyly of Mustelinae. In contrast to the well-resolved relationships among the three subfamilies (MP and ML $B S \geq 90 \%$; $P P=1.00$ ), the phylogenetic position of Mephitinae in Caniformia was ambiguous. Mephitinae, the pinnipeds (including three aquatic carnivoran families, Phocidae, Odobenidae and Otariidae), Procyonidae/non-mephitine Mustelidae, and Ursidae (plus Ailuridae) collapse into an unresolved polytomy.

The $\mathrm{ML}$ (model=HKY+G) and $\mathrm{pBI}$ trees based on $\beta$ fibrinogen intron 4 had nearly the same topology as the MP tree and showed similar support values. Of the 514 aligned nucleotides, 207 (40.27\%) were variable and 114 (22.18\%) were phylogenetically informative. The branch-and-bound search found six most parsimonious trees 273 steps long. As shown in Fig. 3B, Lutrinae and Mustela were most closely related, with high support (MP and $\mathrm{ML} B S>85 \%$; $\mathrm{PP}=0.98$ ), while the placements of Melinae and Martes were not resolved, although they formed a robust clade with Lutrinae and Mustela (MP and ML BS>95\%; $P P=1.00$ ). The striking feature of the FGB4 gene tree in contrast to that of FGB7 was the sister-grouping of Mephitinae and Ailuridae (the red panda), but this relationship was poorly supported in all tree-building methods (MP BS $=53 \%$; $M L \quad B S<50 \%$; $\mathrm{PP}=0.65$ ).

\section{Phylogenetic information in orthologous MIRs}

MP analysis of the orthologous MIRs embedded in $\beta$ fibrinogen intron 7 (alignment positions 82-275) recovered a similar, but less-resolved and lower-supported tree (Fig. 4A) compared to the trees based on non-MIRs sequences in FGB7 (Fig. 4B) and the entire FGB7 sequences (Fig. 3A). Of the 194 aligned nucleotides, $86(44.33 \%)$ were variable and $57(29.38 \%)$ were phylogenetically informative. The ML (model=K80) and $\mathrm{pBI}$ analyses produced the same topologies as the parsimony analysis. As shown in Fig. 4A, most interfamilial relationships across Caniformia were not resolved due to extremely low nodal support and formed a bush-like tree topology. With regard to the Mustelidae, only the monophyly of the non-mephitine mustelid clade (MP $\mathrm{BS}=76 \%$; $\mathrm{ML} \mathrm{BS}=71 \%$; $\mathrm{PP}=0.70$ ) and the close affinity of Lutrinae and Mustela within the clade (MP BS=97\%; ML $\mathrm{BS}=97 \% ; \mathrm{PP}=1.00$ ) were supported.

It appears that the non-MIR sequences retained more phylogenetic signal (Fig. 4B) and thus contributed more to the whole FGB7 tree and resolution of Caniformia phylogeny. The only exception is that all analyses of non-MIR sequences weakly supported Mephitinae as the sister taxon to the pinnipeds (MP BS=59\%; $M L B S=58 \%$; $P P=0.80$ ), a relationship absent from the whole FGB7 tree. This relationship has not been reported in previous studies.

\section{Phylogenetic analyses of combined data set}

We retrieved most sequence data for two other nuclear genes, IRBP exon 1 (1186 bp in the alignment) and TTR intron 1 (910 bp in the alignment), and one mitochondrial protein-coding gene, ND2 (1044bp in the alignment), for the same set of taxa sampled in this study from the GenBank database and complemented them with sequences newly produced here (Table 1). These sequence data were combined with our new data sets for phylogenetic analyses. The combined aligned character matrix comprised 4272 nucleotides, of which 1850 (43.31\%) were variable and 1335 (31.25\%) were parsimony informative.

Compared with either individual gene tree, pooling four nuclear genes and one mt gene demonstrated a clear increase in the resolution of the overall Caniformia tree topology (Fig. 5). Identical relationships among the currently 
A

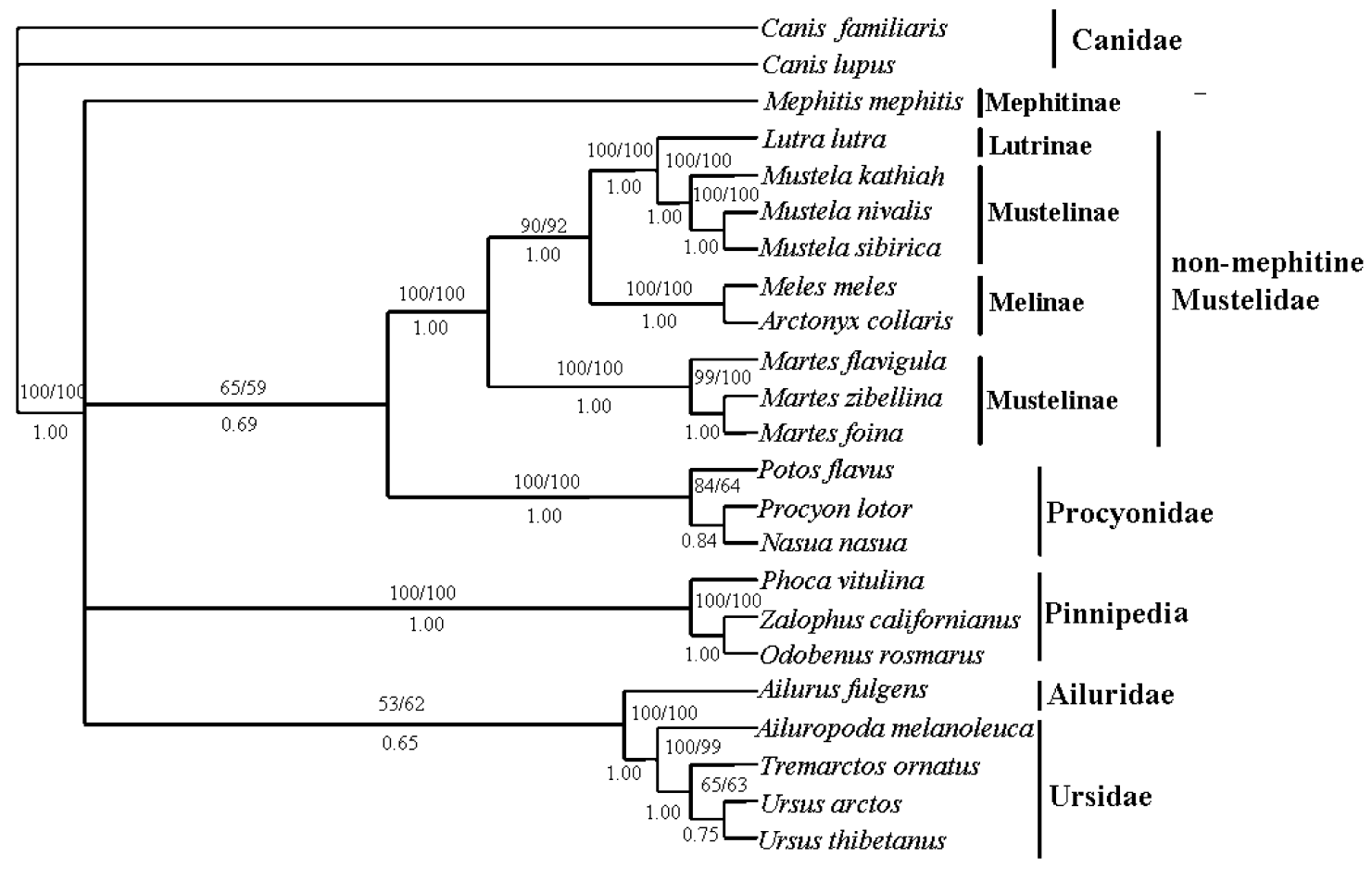

$\mathbf{B}$

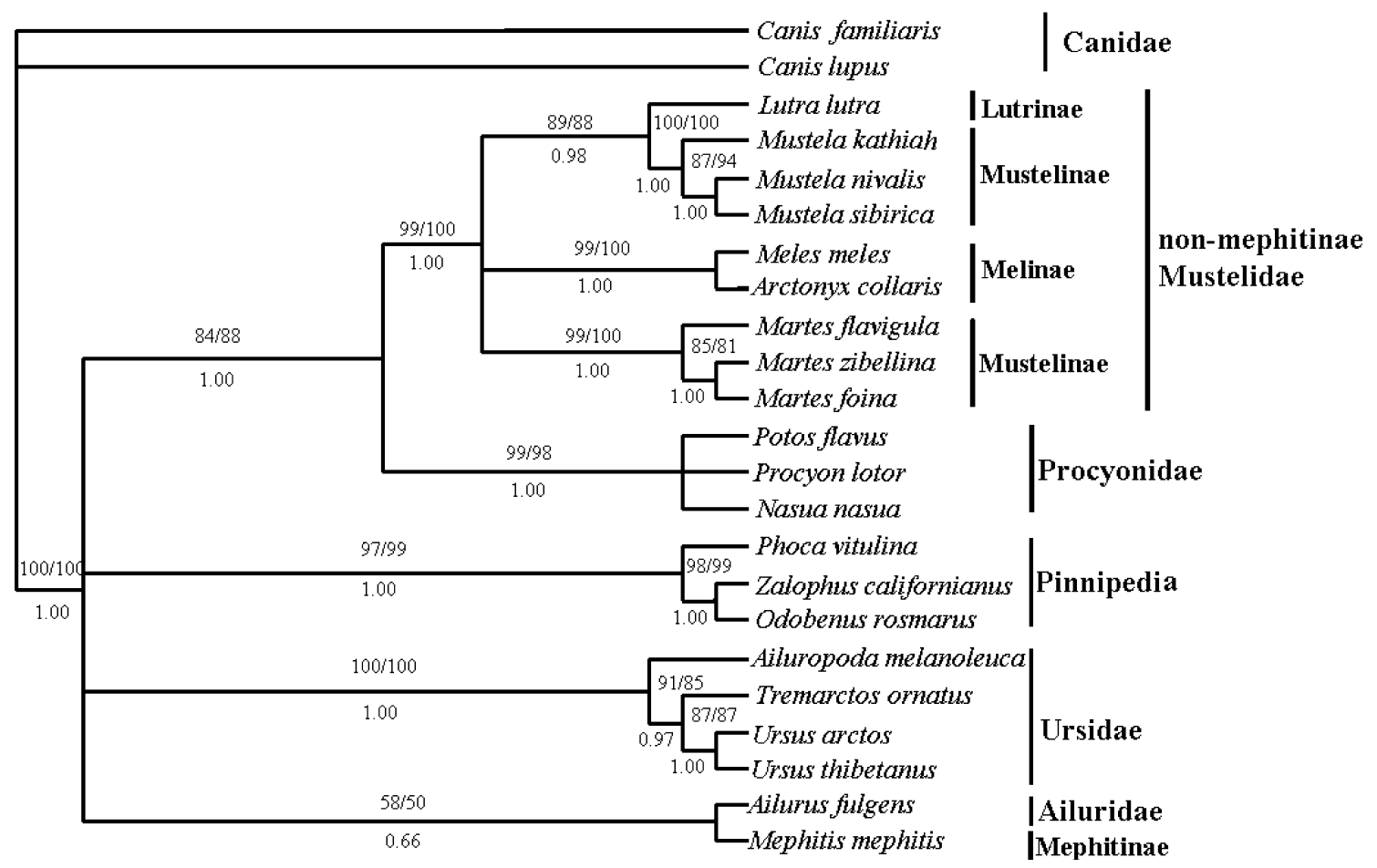

Fig. 3. Consensus phylogenetic trees (50\% majority-rule) based on MP analyses of (A) $\beta$-fibrinogen intron 7 and (B) $\beta$-fibrinogen intron 4 sequences. Groups that appeared in $50 \%$ or more of the trees were retained. $\mathrm{ML}$ and $\mathrm{pBI}$ analyses recovered tree topologies nearly identical to those from the MP analyses. Bootstrap support (MP/ML) and posterior probability (PP) are shown above and below branches, respectively. 
A

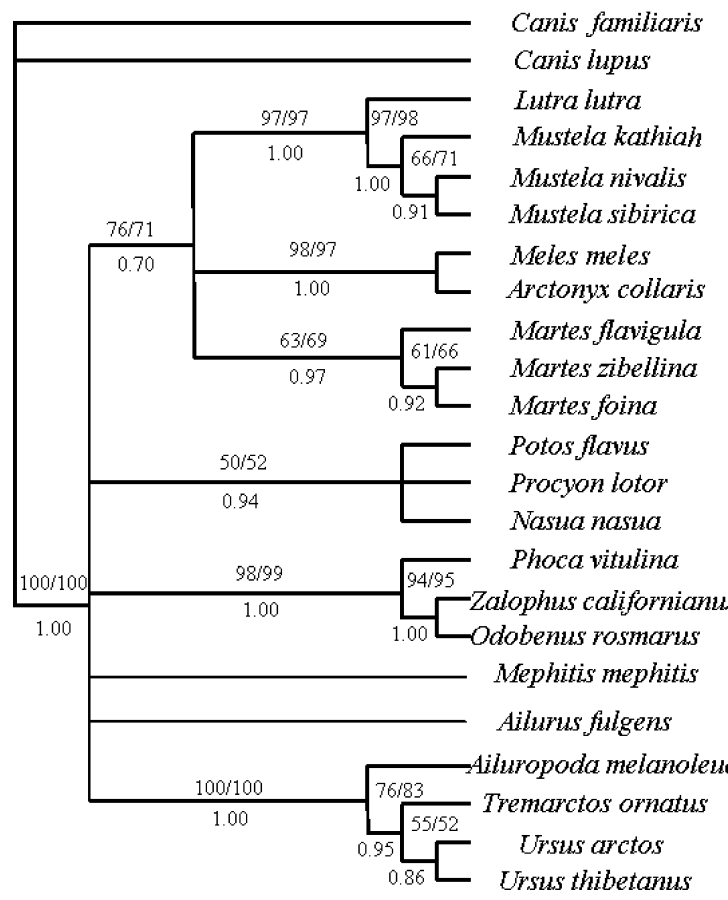

B

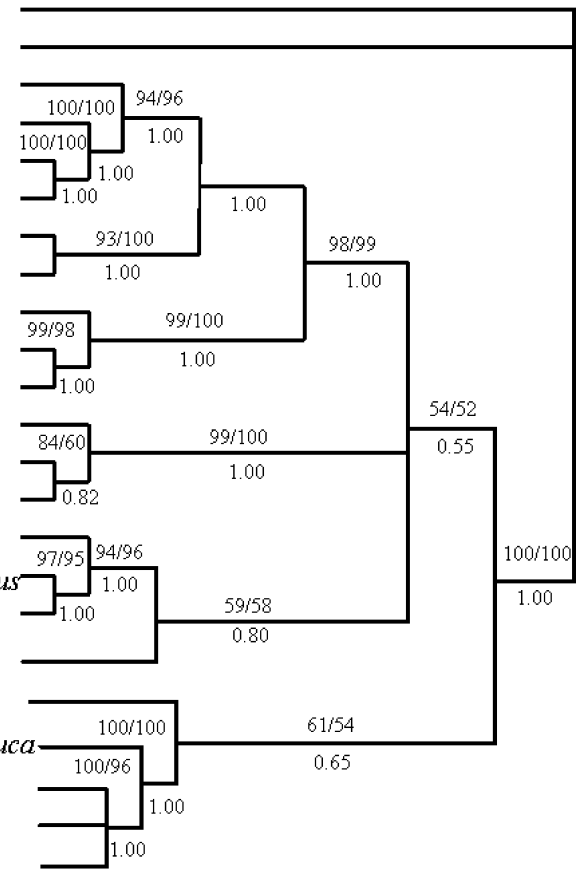

Fig. 4. Phylogenetic trees based on MP analyses of (A) orthologous MIR sequences embedded in $\beta$-fibrinogen intron 7 (only a single most parsimonious tree was found) and (B) non-MIR sequences in $\beta$-fibrinogen intron 7 (only a single most parsimonious tree was found). Groups that appeared in $50 \%$ or more of the trees were retained. $\mathrm{ML}$ and $\mathrm{pBI}$ analyses recovered tree topologies nearly identical to those from the MP analyses. Bootstrap support (MP/ML) and posterior probability (PP) are shown above and below branches, respectively.

A

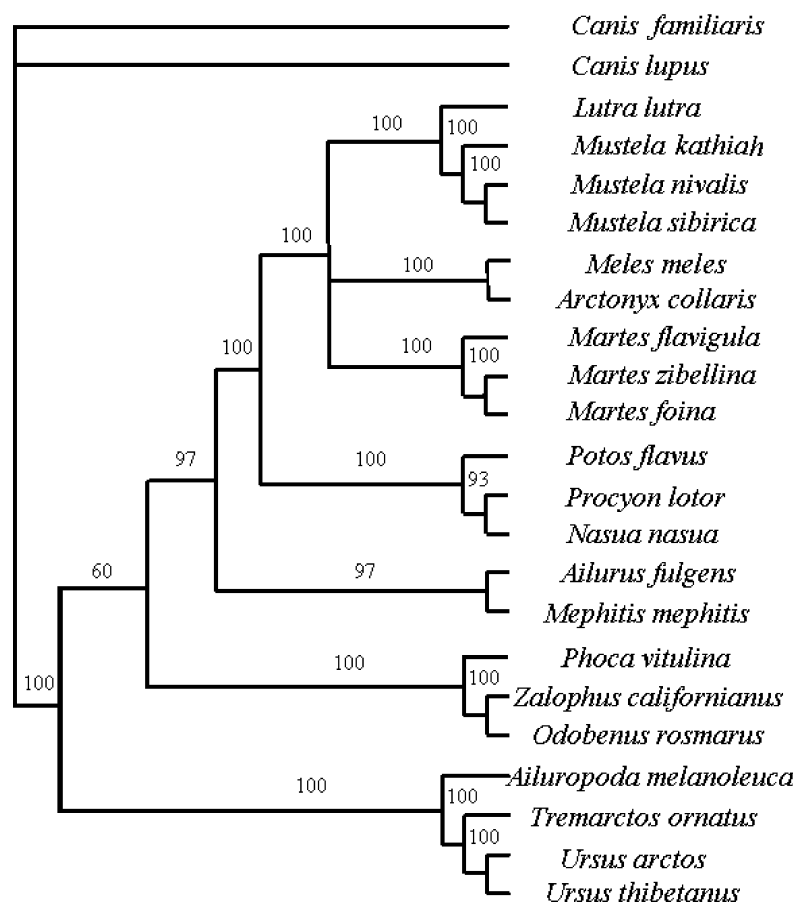

B

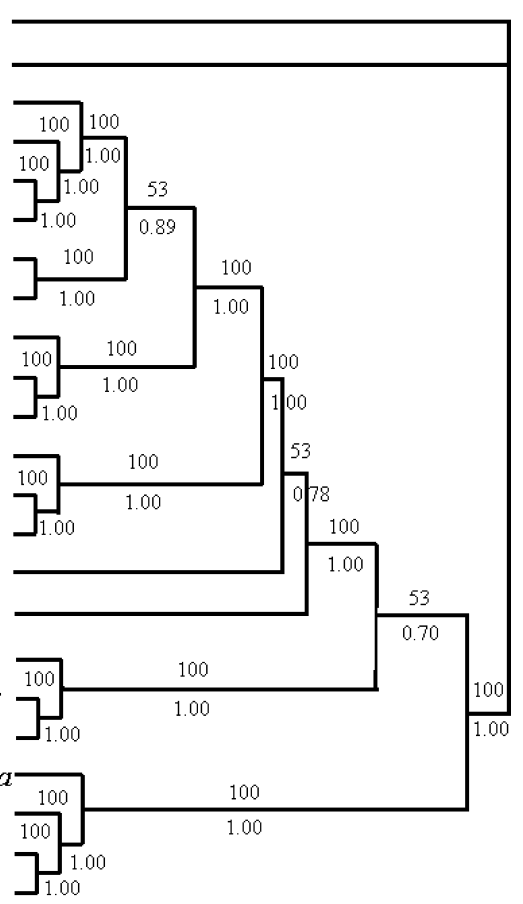

Fig. 5. Phylogenetic trees based on (A) MP (only a single most parsimonious tree was found) and (B) ML/pBI analyses of concatenated sequences from four nuclear genes and one $\mathrm{mt}$ gene. Groups that appeared in 50\% or more of the trees were retained. Bootstrap support (MP/ $\mathrm{ML}$ ) and posterior probabilities (PP) are shown. 
recognized caniform families were obtained, regardless of the analytical approach. Ailuridae was placed as the closest taxon to the Procyonidae/non-mephitine mustelid clade, followed by the pinnipeds and Ursidae (including Ailuridae). However, for Mustelidae, the branching orders for subfamilies were different between the MP and $\mathrm{ML} / \mathrm{pBI}$ analyses. The MP analysis (Fig. 5A; one most parsimonious tree 4402 steps long) resulted in a mustelid clade (including Mephitinae; groups that appeared in $50 \%$ or more of the trees were retained) identical to our FGB4 result (Fig. 3B) but with improved nodal supports, especially in the case of the close relatedness between Mephitinae and Ailuridae (MB $\mathrm{BS}=97 \%$ ) The $\mathrm{ML}$ (model=GTR+l+G) and pBI analyses (Fig. $5 \mathrm{~B})$ produced a tree where relationships among Mustelinae, Lutrinae, and Melinae are the same as in the FGB7 tree (Fig. 3A). Mephitinae, however, was found to emerge after the divergence of Ursidae and the pinnipeds but before divergence of Ailuridae and Procyonidae/non-mephitine Mustelidae (ML BS=53\%; $\mathrm{PP}=0.78$ ), a relationship not recovered by our two nuclear single-gene analyses.

\section{DISCUSSION}

Here, we identified new members of the CAN SINE family, short interspersed nuclear elements specifically present in Order Carnivora. The most interesting feature is the presence of two perfect CAN SINEs joined in tandem (separated by a 9-bp spacer) in the alignment of Mephitis mephitis $\beta$-fibrinogen intron 7 . Sequence analyses indicated that they (Sku7-ins-1 and Sku7-ins-2) arose by two successive insertion events, as evidenced by the existence of two sets of direct terminal repeats (Figs. 1,2). This dimer-like structure is different from those resulting form previously reported primate $A l u$, rodent $M E N, B 1-d I D$, mosquito Twin, and galago SINE type II dimerization events, which involved a fusion of two monomers (related or unrelated) flanked by a set of short direct repeats. They retroposed into the host genome as a single element (Daniels and Deininger, 1985; Quentin, 1992; Jurka and Zuckerkandl, 1991; Serdobova and Kramerov, 1998; Feschotte et al., 2001; Kramerov and Vassetzky, 2001) rather than as two SINE units integrated nearby, as observed in the present study. We know of no examples of successive SINE insertions in such close proximity to a preexisting SINE. Our previous study on $\beta$ fibrinogen intron 7 showed that additional SINE sequences tend to insert into previously existing SINE elements (i.e., orthologous MIRs; Yu and Zhang, 2005b). The present interesting observation from the same intron of Mephitis mephitis corroborated the earlier finding, as illustrated by two tandemly arranged CAN SINE insertions and their obvious integration adjacent to an MIR (Figs. 1A, 2), and led us to speculate that the insertion mode of SINEs may be more complicated and diverse than previously recognized. Taken together, we are convinced that more interesting evolutionary features of the two intronic sequences will be discovered when more mammalian taxa are studied.

Our independent research on this intron in various mammals has revealed a high sporadic incidence of SINE elements in $\beta$-fibrinogen intron 7 ( $Y u$ and Zhang, 2005b). The finding of Mephitis mephitis CAN SINEs here attests again to the widely distributed nature of SINE amplification in this intronic region, though the possible impact of these abun- dant insertions on mammalian evolution and speciation remains to be determined. In addition, we also isolated a new CAN SINE located within another intronic region of the same gene (i.e., within $\beta$-fibrinogen intron 4) from Lutra lutra. Up to now, CAN SINE elements in Mephitis mephitis and Lutra lutra have only been discovered by analyzing the first intron of the transthyretin gene (Genbank Accession Nos. AF306948 and AF039734; Zehr et al., 2001; Vassetzky and Kramerov, 2002). We are the second group to detect new CAN SINEs present in other intron sequences of these two species. However, unlike the CAN SINEs reported here, the previously discovered CAN SINEs were produced by an orthologous insertion before the divergence of Caniformia. Sequence analysis showed the average sequence divergence between our new CAN SINEs and those previously discovered is $31.7 \%$ (Sku7-ins-1) and 30.7\% (Sku7-ins-2) for Mephitis mephitis and $32.1 \%$ for Lutra lutra.

The MIR insertion in the orthologous locus of $\beta$-fibrinogen intron 7 allowed us to examine the potential phylogenetic signals harbored in MIR sequences. Zehr et al. (2001) made the first attempt to explore whether nucleotide sequence characters within SINEs contain useful information for the estimation of organismal phylogeny; they analyzed orthologous CAN SINEs from a phylogenetic point of view and compared the phylogenetic results with those based on the transthyretin intron 1 sequence in which the CAN SINE is located. Their study showed that the tree topology based on CAN SINE sequences was significantly different from that based on transthyretin intron 1 , as a result of homoplasy introduced by an increased substitution rate for the CAN SINEs. Although the MIR elements in our case did not show a significant increase in substitution rate over the non-MIR sequences in $\beta$ fibrinogen intron 7 (data not shown), their analysis recovered a poor tree, in terms of both tree topology and nodal supports, compared to the non-MIR and whole FGB7 trees, especially in the case of the basal clades (Fig. 4A). It may be inferred that nucleotide sequence data from SINEs should be used with caution in phylogeny reconstruction, because phylogenetic hypotheses derived from their analyses are shown to be rather less sensitive and reliable, possibly due to short sequence length, limited informative content, or aberrant evolutionary patterns. Of course, more investigation with respect to this issue will be needed.

Our study not only explored the mode of evolution in the SINE elements isolated from the two new intronic sequences, but also provided several insightful results for mustelid phylogeny by separate and simultaneous analyses of the two new intronic sequences and two other nuclear and one $\mathrm{mt}$ genes previously reported, although the resulting tree topologies were not identical for different treebuilding methods and gene partitions. In all analyses, the assemblage of Mustelinae, Lutrinae, and Melinae (i.e, nonmephitine Mustelidae) was recovered with confidence (BS $\geq 99 \%$ and $P P=1.00$ ); moreover, two clades within Mustelinae were clearly recognized, genera Mustela and Martes ( $\mathrm{BS} \geq 99 \%$ and $\mathrm{PP}=1.00)$. Notably, Mustela was found to consistently group with Lutrinae to the exclusion of Martes (BS> $85 \%$ and $P P>0.95$ ), indicating the paraphyly of Mustelinae. The sister-grouping of Mustela with Mustelinae and Lutrinae recovered here was in accordance with the results of previous studies based on analyses of other mito- 
chondrial and nuclear gene combinations (Sato et al., 2003, 2004, 2006; Koepfli and Wayne, 2003; Marmi et al., 2004; Delisle and Strobeck, 2005; Flynn et al., 2005; Fulton and Strobeck, 2006; Yonezawa et al., 2007). The traditional view from fossil evidence (Wolsan, 1999) and from morphological data (Hunt, 1974; Wozencraft, 1989; Wyss and Flynn, 1993; Bryant et al., 1993), as well as from mustelid supertree construction (Bininda-Emonds et al., 1999), in which Lutrinae was closer to Mephitinae, was not supported in this study. The monophyly of the subfamilies in Mustelidae has also been a subject of controversies arising from previous investigations. Among them, Mustelinae, the largest and most diverse subfamily in Mustelidae, has been gradually accepted to be a paraphyletic group (Bryant et al., 1993; Dragoo and Honeycutt, 1997; Koepfli and Wayne, 1998, 2003; Hosoda et al., 2000; Sato et al., 2003, 2004, 2006; Marmi et al., 2004; Delisle and Strobeck, 2005; Flynn et al., 2005; Fulton and Strobeck, 2006; Yonezawa et al., 2007), although there are still diverging views from molecular and morphological data (Bininda-Emonds et al., 1999). Our analyses confirmed non-monophyletic origin of this subfamily, as evidenced by its inclusion of Lutrinae.

Our analyses in this paper provide evidence that Melinae is more closely associated with Lutrinae/Mustela than is Martes (Figs. 3A, 5B). This relationship received especially good support from the $\beta$-fibrinogen intron 7 tree $(B S \geq 90 \%$ and $P P=1.00$ ), a result that has not been obtained in previous analyses. Three synapomorphic substitutions were found to support this relationship in our FGB7 data set. The alternative hypotheses proposed in previous studies, including a closer affinity of Martes to the Lutrinae/Mustela clade inferred from the analysis of mitochondrial genes (Marmi et al., 2004; Delisle and Strobeck, 2005), nuclear genes (Sato et al., 2006; Fulton and Strobeck, 2006), and combined mitochondrial and nuclear genes (Sato et al., 2003; Yonezawa et al., 2007), and the possible sister status of Melinae and Martes inferred from the $\mathrm{NJ}$ analysis of Cyt B (Sato et al., 2003) and combined analyses of the five nuclear sequence data sets (Koepfli and Wayne, 2003), were not recovered by any of the present analysis. Evidence from additional genes is necessary to test the current phylogenetic hypothesis, considering that the $\mathrm{ML}$ and $\mathrm{pBI}$ inferences from the concatenated data set failed to convincingly retain this relationship ( $M L B S=53 \%$ and $P P=0.89$ ).

Our analyses unanimously support the rather distant association of Mephitinae to the rest of mustelids, an observation consistent with the increasing molecular evidence that Mephitinae should be elevated to a separate family (Vrana et al., 1994; Ledje and Arnason, 1996a, b; Dragoo and Honeycutt, 1997; Flynn et al., 2000; Marmi et al., 2004; Delisel and Strobeck, 2005; Flynn et al., 2005; Sato et al., 2006; Fulton and Strobeck, 2006), although its precise position in Caniformia remains unclear in our study. An earlier proposal, based on morphological evidence, that Mephitinae belongs in Mustelidae and shows closer affinity with Melinae (Simpson, 1945) or Lutrinae (Wozencraft, 1989; Wyss and Flynn, 1993; Bryant et al., 1993; Wolsan, 1999), was not recovered in any of our analyses. We found Mephitinae to diverge before the other mustelids and the monophyletic Procyonidae in all cases; however, it was placed as the sister taxon either to Ailuridae in the $\beta$-fibrinogen intron 4 (Fig.
3B) and concatenated MP trees (Fig. 5A) or to the clade containing Ailuridae and Procyonidae/non-mephitine Mustelidae in the concatenated $\mathrm{ML} / \mathrm{pBI}$ trees (Fig. 5B). In recent nucleotide sequence studies of Caniformia, the interrelationship among Mephitinae, Procyonidae/non-mephitine Mustelidae, and Ailuridae has been an unresolved trichotomy. There are three resultant hypotheses: (1) Mephitinae is more closely related to Ailuridae than to Procyonidae/nonmephitine Mustelidae (Flynn et al., 2000; Delisle and Strobeck, 2005; Sato et al., 2006); (2) Mephitinae is more closely related to Procyonidae/non-mephitine Mustelidae than to Ailuridae (Marmi et al., 2004; Ledje and Arnason, 1996b; Flynn et al., 2005); and (3) Ailuridae and Mephitinae are successively more distant outgroups to Procyonidae/ non-mephitine Mustelidae (Fulton and Strobeck, 2006; Sato et al., 2006). Both hypotheses (1) and (3) are supported in our analyses, although hypotheses (1) received more robust support from the concatenated MP tree (MP BS=97\%). Therefore, more data are needed to test these alternative phylogenetic hypotheses in relation to Mephitinae.

Although neither intron from the $\beta$-fibrinogen gene alone has resolved all of the phylogenetic controversy concerning Mustelidae, our results indicate that these two nuclear regions are potentially serviceable in resolving some relationships among mustelids. The $\beta$-fibrinogen intron 7 region provides good resolution in the non-mephitine mustelid part of the Caniformia tree, while $\beta$-fibrinogen intron 4 contains information informative for the placement of Mephitinae, albeit with less robust support. A recent similar work on higher-level caniform phylogeny has revealed that these two introns of the $\beta$-fibrinogen gene are informative for carnivore relationships at the genus level or above ( $\mathrm{Yu}$ and Zhang, 2006). Surprisingly, our study here, which included additional taxa of Mustelidae, finds that the relationships estimated among caniform families are rather limited, a result inconsistent with the conclusion drawn by $\mathrm{Yu}$ and Zhang (2006). This inconsistency may have been caused by the use of different outgroups (Canidae in Caniformia vs Felidae in Feliformia) or by the unbalanced sampling of representatives of caniform families (more mustelid taxa here compared to their study). We thus also selected two feliform species, Panthera leo and Felis catus (Accession nos. AY634374, AY634379, AY882043, and AY882044), which were used as outgroup taxa in $\mathrm{Yu}$ and Zhang (2006), for rooting in the $\beta$-fibrinogen intron 4 and 7 data sets. Phylogenetic analyses of 23 caniform carnivores using available felid species as outgroups gave a tree topology identical to that obtained using Canidae as the outgroup. Therefore, it seems that the inclusion of more mustelid taxa here likely explains the inconsistency. On the other hand, it is also important to note that although the combined data set containing four nuclear and one mitochondrial genes apparently provided phylogenetic signals useful for reconstructing the higher-level phylogeny of Caniformia, no significant improvement in the resolution of Mustelidae relationships was obtained compared with the individual analyses of the two new introns, possibly due to heterogeneous rates of evolution and levels of homoplasy between the gene partitions. Taken together, additional genetic markers are in urgent need to resolve the problematic regions that caused topological instability in the mustelid phylogeny in the present study. The supplementary 
data for this article can be found online at "http://dx.doi.org/ 10.2108/zsj.25.662.s1".

\section{ACKNOWLEDGMENTS}

This work was supported by grants from the National Basic Research Program of China (Program 973, 2007CB411600), the National Natural Science Foundation of China (Grant Nos. 30600067 and 30621092), and the Bureau of Science and Technology of Yunnan Province.

\section{REFERENCES}

Altschul SF, Madden TL, Schäffer AA, Zhang J, Zhang Z, Miller W, Lipman DJ (1997) Gapped BLAST and PSI-BLAST: a new generation of protein database search programs. Nucleic Acids Res 25: 3389-3402

Barker FK (2004) Monophyly and relationships of wrens (Aves: Troglodytidae): a congruence analysis of heterogeneous mitochondrial and nuclear DNA sequence data. Mol Phylogenet Evol 31: 486-504

Betley JN, Frith MC, Graber JH, Choo S, Deshler JO (2002) A ubiquitous and conserved signal for RNA localization in chordates. Curr Biol 12: 1756-1761

Bininda-Emonds ORP, Gittleman JL, Purvis A (1999) Building large trees by combining phylogenetic information: A complete phylogeny of the extant Carnivora (Mammalia). Biol Rev 74: 143175

Bryant HN, Russell AP, Fitch WB (1993) Phylogenetic relationships within the extant Mustelidae (Carnivora): appraisal of the cladistic status of the Simpsonian subfamilies. Zool J Linn Soc 108: 301-334

Coltman DW, Wright JM (1994) Can SINEs: a family of tRNAderived retroposons specific to the superfamily Canoidea. Nucleic Acids Res 22: 2726-2730

Creer S, Malhotra A, Thorpe RS (2003) Assessing the phylogenetic utility of four mitochondrial genes and a nuclear intron in the Asian pit viper genus, Trimeresurus: separate, simultaneous, and conditional data combination analyses. Mol Biol Evol 20: $1240-1251$

Daniels GR, Deininger PL (1985) Integration site preferences of the Alu family and similar repetitive DNA sequences. Nucleic Acids Res 13: 8939-8954

Deininger PL (1989) SINEs: short interspersed repeated DNA elements in higher eukaryotes. In "Mobile DNA" Ed by DE Berg, MM Howe, American Society of Microbiology, Washington DC, pp 619-636

Delisle I, Strobeck C (2005) A phylogeny of the Caniformia (order Carnivora) based on 12 complete protein-coding mitochondrial genes. Mol Phylogenet Evol 37: 192-201

Dragoo JW, Honeycutt RL (1997) Systematics of mustelid-like carnivores. J Mamm 78: 426-443

Eisenberg JF (1989) An introduction to the Carnivora. In "Carnivore Behavior, Ecology, and Evolution" Ed by JL Gittleman, Cornell University Press, Ithaca, NY, pp 1-9

Feschotte C, Fourrier N, Desmons I, Mouchès C (2001) Birth of a retroposon: the Twin SINE family from the vector mosquito Culex pipiens may have originated from a dimeric tRNA precursor. Mol Biol Evol 18: 74-84

Flynn JJ, Nedbal MA (1998) Phylogeny of the Carnivora (Mammalia): congruence vs incompatibility among multiple data sets. Mol Phylogenet Evol 9: 414-426

Flynn JJ, Nedbal MA, Dragoo JW, Honeycutt RL (2000) Whence the red panda? Mol Phylogenet Evol 17: 190-199

Flynn JJ, Finarelli JA, Zehr S, Hsu J, Nedbal MA (2005) Molecular phylogeny of the Carnivora (Mammalia): assessing the impact of increased sampling on resolving enigmatic relationships. Syst Biol 54: 317-337
Fulton TL, Strobeck C (2006) Molecular phylogeny of the Arctoidea (Carnivora): effect of missing data on supertree and supermatrix analyses of multiple gene data sets. Mol Phylogenet Evol 41: 165-181

Hosoda T, Suzuki H, Harada M, Tsuchiya K, Han SH, Zhang $\mathrm{Y}$, Kryukov AP, Lin LK (2000) Evolutionary trends of the mitochondrial lineage differentiation in species of genera Martes and Mustela. Genes, Genet Syst 75: 259-267

Hunt RM Jr (1974) The auditory bulla in Carnivora: an anatomical basis for reappraisal of carnivore evolution. J Morphol 143: 21 76

Jurka J, Zuckerkandl E (1991) Free left arms as precursor molecules in the evolution of Alu sequences. J Mol Evol 33: 49-56

Jurka J, Zietkiewicz E, Labuda D (1995) Ubiquitous mammalianwide interspersed repeats (MIRs) are molecular fossils from the Mesozoic era. Nucleic Acids Res 23: 170-175

Koepfli KP, Wayne RK (1998) Phylogenetic relationships of otters (Carnivora; Mustelidae) based on mitochondrial cytochrome b sequences. J Zool 246: 401-416

Koepfli KP, Wayne RK (2003) Type 1 STS markers are more informative than cytochrome $b$ in phylogenetic reconstruction of the Mustelidae (Mammalia: Carnivora). Syst Biol 52: 571-593

Kohany O, Gentles AJ, Hankus L, Jurka J (2006) Annotation, submission and screening of repetitive elements in Repbase: RepbaseSubmitter and Censor. BMC Bioinform 7: 474

Kramerov DA, Vassetzky NS (2001) Structure and origin of a novel dimeric retroposon B1-diD. Mol Biol Evol 52: 137-143

Kumar S, Tamura K, Nei M (2004) MEGA3: integrated software for molecular evolutionary genetics analysis and sequence alignment. Brief Bioinform 5: 150-163

Larget B, Simon DL (1999) Markov chain Monte Carlo algorithms for the Bayesian analysis of phylogenetic trees. Mol Biol Evol 16: 750-759

Lavrentieva MV, Rivkin MI, Shilov AG, Kobetz ML, Rogozin IB, Serov OL (1989) B2-like repetitive sequence of American mink genome. Dokl Akad Nauk SSSR 307: 226-230

Ledje C, Arnason U (1996a) Phylogenetic analyses of complete cytochrome $b$ genes of the order carnivora with particular emphasis on the Caniformia. J Mol Evol 42: 135-144

Ledje C, Arnason U (1996b) Phylogenetic relationships within caniform carnivores based on analyses of the mitochondrial $12 \mathrm{~S}$ rRNA gene. J Mol Evol 43: 641-649

Maraia RJ (1995) The impact of short interspersed elements (SINEs) on the host genome. Springer-Verlag, New York

Marmi J, López-Giráldez J, Domingo-Roura X (2004) Phylogeny, evolutionary history and taxonomy of the Mustelidae based on sequences of the cytochrome $b$ gene and a complex repetitive flanking region. Zool Scr 33: 481-499

Minnick MF, Stillwell LC, Heinerman JM, Stiegler GL (1992) A highly repetitive DNA sequence possibly unique to canids. Gene 110: 235-238

Okada N (1991) SINEs: short interspersed repeated elements of the eukaryotic genome. Trends Ecol Evol 6: 358-361

Posada D, Crandall KA (1998) Modeltest: testing the model of DNA substitution. Bioinformatics 14: 817-818

Prychitko TM, Moore WS (1997) The utility of DNA sequences of an intron from the $\beta$-fibrinogen gene in phylogenetic analysis of woodpeckers (Aves: Picidae). Mol Phylogenet Evol 8: 193-204

Quentin Y (1992) Origin of the Alu family: a family of Alu-like monomers gave birth to the left and the right arms of the Alu elements. Nucleic Acids Res 20: 3397-401

Rogers JH (1985) The origin and evolution of retroposons. Int Rev Cytol 93: 187-279

Ronquist F, Huelsenbeck JP (2003) MrBayes 3: Bayesian phylogenetic inference under mixed models. Bioinformatics 19: 15721574

Sambrook E, Fritsch F, Maniatis T (1989) Molecular Cloning. Cold 
Spring Harbor Press, Cold Spring Harbor, NY

Sato JJ, Hosoda T, Wolsan M, Tsuchiya K, Yamamoto Y, Suzuki H (2003) Phylogenetic relationships and divergence times among mustelids (Mammalia: Carnivora) based on nucleotide sequences of the nuclear interphotoreceptor retinoid binding protein and mitochondrial cytochrome b genes. Zool Sci 20: 243-264

Sato JJ, Hosoda T, Wolsan M, Suzuki H (2004) Molecular phylogeny of arctoids (Mammalia: Carnivora) with emphasis on phylogenetic and taxonomic positions of the ferret-badgers and skunks. Zool Sci 21: 111-118

Sato JJ, Wolsan M, Suzuki H, Hosoda T, Yamaguchi Y, Hiyama K, Kobayashi M, Minami S (2006) Evidence from nuclear DNA sequences sheds light on the phylogenetic relationships of Pinnipedia: single origin with affinity to Musteloidea. Zool Sci 23: 125-146

Serdobova IM, Kramerov DA (1998) Short retroposons of the B2 superfamily: evolution and application for the study of rodent phylogeny. J Mol Evol 46: 202-214

Shedlock AM, Okada N (2000) SINE insertions: powerful tools for molecular systematics. BioEssays 22: 148-160

Simpson GG (1945) The principles of classification and a classification of mammals. Bull Am Mus Nat Hist 85: 1-350

Smit AF, Riggs AD (1995) MIRs are classic, tRNA-derived SINEs that amplified before the mammalian radiation. Nucleic Acids Res 23: 98-102

Swofford DL (2002) PAUP*: Phylogenetic Analysis Using Parsimony ( ${ }^{*}$ and Other Methods), Version 4.0b10. Sinauer Associates, Sunderland, MA

Thompson JD, Gibson TJ, Plewniak F, Jeanmougin F, Higgins DG (1997) The clustalx windows interface: flexible strategies for multiple sequence alignment aided by quality analysis tools. Nucleic Acids Res 24: 4876-4882

Vassetzky NS, Kramerov DA (2002) CAN-a pan-carnivore SINE family. Mamm Genome 13: 50-57

Vrana PB, Milinkovitch MC, Powell JR, Wheeler WC (1994) Higher level relationships of the arctoid Carnivora based on sequence data and "total evidence" Mol Phylogenet Evol 3: 47-58

Wang TH, Johnson N, Zou J, Bols N, Secombes CH (2004) Sequencing and expression of the second allele of the interleukin-1 $\beta 1$ gene in rainbow trout (Oncorhynchus mykiss): identification of a novel SINE in the third intron. Fish Shellfish Immun 16: $335-358$

Weiner AM, Deininger PL, Efstratiadis A (1986) Nonviral retroposons: genes, pseudogenes, and transposable elements generated by the reverse flow of genetic information. Annu Rev Biochem 55: 631-661
Willemsen GF (1992) A revision of the Pliocene and Quaternary Lutrinae from Europe. Scr Geol 101: 1-115

Wolsan M (1993) Phylogeny and classification of early European Mustelida (Mammalia: Carnivora). Acta Theriol 38: 345-384

Wolsan M (1999) Oldest mephitine cranium and its implications for the origin of skunks. C Acta Palaeont Polon 44: 223-230

Wolsan M (2005) Fossil-based minimum divergence dates for the major clades of musteloid carnivorans. In "Abstracts of Plenary, Symposium, Poster and Oral Papers Presented at Ninth International Mammalogical Congress (IMC 9)", pp 372-373

Wozencraft WC (1989) The phylogeny of the recent carnivores. In "Carnivore Behavior, Ecology, and Evolution" Ed by JL Gittleman, Cornell University Press, Ithaca, NY, pp 495-535

Wyss AR, Flynn JJ (1993) A phylogenetic analysis and definition of the Carnivora. In "Mammal Phylogeny" Ed by FS Szalay, M Novacek, M McKenna, Springer-Verlag, NY, pp 32-52

Yonezawa T, Nikaido M, Kohno N, Fukumoto Y, Okada N, Hasegawa $M(2007)$ Molecular phylogenetic study on the origin and evolution of Mustelidae. Gene 396: 1-12

Yoder AD, Burns MM, Zehr S, Delefosse T, Veron G, Goodman SM, Flynn JJ (2003) Single origin of Malagasy carnivore from an African ancestor. Nature 421: 734-737

Yu L, Li QW, Ryder OA, Zhang YP (2004a) Phylogeny of the bears (Ursidae) based on nuclear and mitochondrial genes. Mol Phylogenet Evol 32: 480-494

Yu L, Li QW, Ryder OA, Zhang YP (2004b) Phylogenetic relationships within mammalian order Carnivora indicated by sequences of two nuclear DNA genes. Mol Phylogenet Evol 33: 694-705

Yu L, Zhang YP (2005a) Phylogenetic studies of pantherine cats (Felidae) based on multiple genes, with novel application of nuclear $\beta$-Fibrinogen intron 7 to carnivores. Mol Phylogenet Evol 35: 483-495

Yu L, Zhang YP (2005b) Evolutionary implications of multiple SINE insertions unusually occurred in an intronic region from diverse mammals. Mamm Genome 16: 651-660

Yu L, Zhang YP (2006) Phylogeny of the caniform Carnivora: evidence from multiple genes. Genetica 127: 65-79

Zehr SM, Nedbal MA, Flynn JJ (2001) Tempo and mode of evolution in an orthologous Can SINE. Mamm Genome 12: 38-44

(Received November 6, 2007 / Accepted March 13, 2008) 